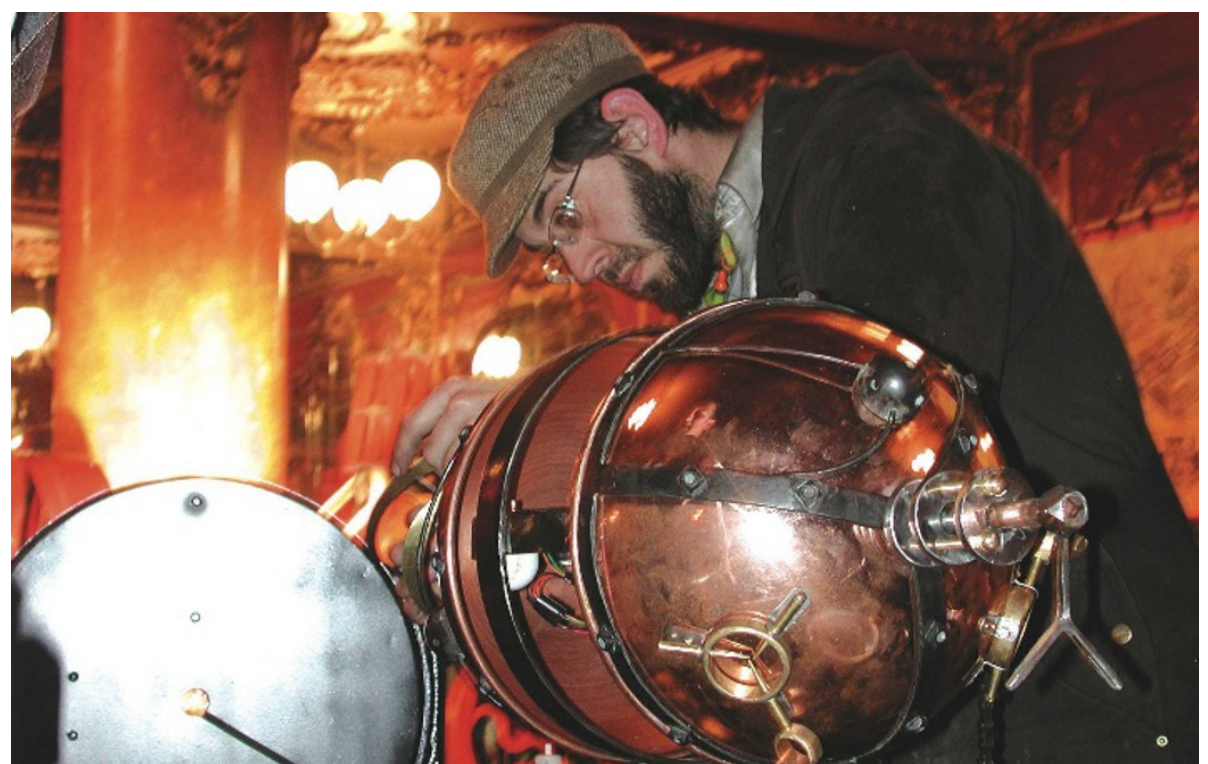

Doctoral student Alan Rorie aims to instil 'a sense of wonder and whimsy' through his machine art.

\title{
HACKING
}

\section{Crafters tinker with technology}

\section{Krista Zala}

A new crafts movement is afoot. Growing numbers of tinkerers are creating custom machines following their own aesthetics. Dabbling with electronics, electrolysis and etching, these contraption-hackers gleefully ignore warranties and dig in, here overhauling a lap-top to achieve a century-old look, or there wiring a pair of contemporary headphones into a gutted antique pair.

Capturing the spirit of the emerging culture, the O'Reilly Emerging Technology Conference that took place this week in San Diego, California, ran sessions on how to make aerial drones and on hacking - beyond gadgets to the body, brain and food. In May, just south of San Francisco, the third annual Maker Faire will bring together craft geeks usually united in cyberspace for a weekend of workshops and tip-swapping.

One subset of these twenty-first century creators looks back to an era when handcrafters designed everyday tools with an elegant flourish. For example, using old gas-lamp arms and chime levers scrounged from a grandfather clock, Sean Slattery, the computer guy at a chemical research and development company in Burlington, Massachusetts, retooled his keyboard and flat-screen monitor to imbue it with vintage Victorian style. "Steampunk is a general rejection of the sameness that globalization is bringing to the world," says Slattery (or Hieronymus Isambard Jake von Slatt, as he is known in steampunk circles).

"Steampunk is to science what civil war reenactions are to history," Slattery explains. The people involved - many of them scientists and engineers - are interested in learning about the history of science. They do so by re-creation, converting electrical lamps to kerosene or fashioning telegraph sounders to tap out web content updates. Their engagement thus becomes personal, tactile and satisfying.

The trend emerged in the 1970s and 1980s as a subgenre of science fiction, which set Victorian characters amid today's technology or in a parallel future universe, where analogue triumphed over digital and the airship prevailed over the aeroplane. The fantastical sensibilities spread from literature into film and video games across Europe, Japan and the United States. The past few years have even seen steampunk pervade fashion and music. The style plays with the parallels between the Industrial Revolution and the Information Revolution - both eras of intense technological and social change. Now part of the wider culture of uploading, downloading, copying, pasting, swapping and re-ordering the world, steampunk applies the philosophy of opensource software to hardware.

Aficionados combine an appreciation of good simple engineering, as embodied by the steam engine, with the 'do it your way' ethos of punk. Steampunk aesthetics, in contrast with the hidden mechanisms and functions of today's gadgets, expose and celebrate intricate machine workings. That said, the builders happily draft plans using modern software and materials.

Tinkering has always been a key way into science. Inquisitive minds bent on learning how the world works have long gone at it with a screwdriver first. Now teachers are enhancing their lessons on electrolysis using Slattery's etchings on confectionery tins and iPods.

For purists, "it's not really steampunk unless it has a steam engine attached to it", says Sean Orlando, artistic director of the Steampunk Tree House, the interactive sculpture installed last year at the Burning Man arts festival in Nevada. The nine-metre-tall tree fashioned from steel pipes, I-beams and an 8,000-kilogram steam engine took five hours to generate the power to run a steam organ; its lights were powered by a solar array.

In San Francisco, the eighth annual Edwardian Ball Weekend this January showcased boilerpowered antique engines. A horizontal engine drove a novelty 'time machine' designed and built by Alan Rorie, a neurobiology doctoral student at Stanford University, California. The 'dihemispheric chronaether agitator' (pictured) is a polished copper sphere, the size of a desk globe, the hemispheres of which spin in opposing directions around a system of gears.

"I want to create interactive art that communicates science to people," says Rorie. Scientists physically experience the world to gain an understanding of systems, he explains, but share only the facts that they find, which deprives their audience of the feel of research. He aims to instill "a sense of wonder and whimsy" with his artwork. His next project is an interactive neuron to teach people about receptive fields.

Krista Zala is a science writer based in Victoria, Canada.

\section{HACKING}

\section{Home cooking with a twist}

\section{Jascha Hoffman}

"I think of cooking as hacking," says Californian computer programmer Marc Powell, who led a 'Kitchen Hack Lab' demonstration at the O'Reilly Emerging Technology Conference in San Diego this week.

In the kitchen, we're all amateur chemists. Protein, carbohydrate, fat and water react to changes in pressure and temperature during cooking. Just as a hardware hacker adapts an electronic device to a new purpose, a food hacker recombines ingredients in unconventional ways.

Powell wants to bring "the red-headed stepchild of molecular gastronomy" to the masses. At Unicorn Precinct XIII in San Francisco, he hosts a 'collaborative supper club'. Guests can sample blood ice cream, chocolate monkfish 